\title{
DISTINGUISHING CONSTITUTIONAL AND STATUTORY INTERPRETATION IN JUDICIAL REVIEW CASES: A BLURRED BOUNDARY LINE
}

\author{
Bisariyadi \\ Mahkamah Konstitusi Republik Indonesia \\ E-mail: bisariyadi@mahkamahkonstitusi.go.id
}

\begin{abstract}
The establishment of the Constitutional Court to hold power of reviewing the constitutionality of Laws raises discourse on the distinction between constitutional interpretation and statutory interpretation. In judicial review cases, the separation, either in common law or civil law tradition, between the two interpretations is not clearly distinguished. The Indonesian Constitutional Court, in judicial review decisions, shows that the Court does not only interpret constitutional provision. In a number of decisions, the Court has put more emphasis on the use of statutory interpretation. The essay discusses the Constitutional Court practice in the use of constitutional interpretation and statutory interpretation on judicial review cases.
\end{abstract}

Keywords: Constitutional Court, judicial review, constitutional interpretation, statutory interpretation

\begin{abstract}
Abstrak
Keberadaan Mahkamah Konstitusi yang memegang kekuasaan untuk melakukan pengujian Undang-Undang mengungkit wacana pembedaan antara penafsiran konstitusi dengan penafsiran Undang-Undang. Dalam praktek pengujian Undang-Undang, baik pada sistem hukum common law maupun civil law, pemisahan antara keduanya tidaklah terdapat garis batas yang tegas. Mahkamah Konstitusi, dalam perkara pengujian Undang-Undang, tidak hanya melakukan penafsiran konstitusi terhadap pasal-pasal konstitusi. Dalam beberapa kasus pengujian konstitusional, Mahkamah Konstitusi justru lebih menekankan pada penafsiran Undang-Undang. Tulisan ini membahas mengenai praktek yang dilakukan oleh Mahkamah Konstitusi dalam upaya melakukan penafsiran konstitusi dan penafsiran Undang-Undang melalui putusan-putusannya pada perkara pengujian Undang-Undang terhadap Undang-Undang Dasar.
\end{abstract}

Kata Kunci : Mahkamah Konstitusi, pengujian undang-undang, penafsiran konstitusi, penafsiran undang-undang

\section{Introduction}

The Indonesian Constitutional Court (Mahkamah Konstitusi, MK) is the final interpreter of the Constitution. The role is associated with the court's power to review the Laws which are in contradiction with the Constitution as stipulated in article 24C of the 1945 Constitution (UUD 1945). Lawyers, legal scholars, and state institutions may also interpret the Constitution. Nonetheless, the power of the Court to interpret the Constitution is stipulated in the constitution. Hence, whenever the Court has given an interpretation to a certain constitutional provision, it has the force to legally binding all citizens to respect and uphold. Any interpretation by parties shall adhere to the Court's ruling.
A question raised upon the issue that does it mean MK will always provide a constitutional interpretation in carrying out its authority of constitutional review? To answer the question, one must look upon distinction between constitutional interpretation and statutory interpretation. The discussion of this separation is more developed in countries with common law system. ${ }^{1}$ Meanwhile in countries putting more em-

James Allan, “Constitutional Interpretation V. Statutory Interpretation: Understanding the Attractions of "Original Intent"”, Legal Theory, Vol. 6 No. 1, March 2000, p. 109-126; David Feldman, "Statutory Interpretation and Constitutional Legislation, Law Quarterly Review, Vol. 130, 2014, p. 480; Kent Greenwalt, “Are Mental States Relevant for Statutory and Constitutional Interpretation", Cornell Law Review, Vol. 85 Issue 6, 2000, p. 1611-1612. 
phasis on codified laws, such as Indonesia, theoretical discussion on distinction of constitutional and statutory interpretation is not contested at length. The line between constitutional and statutory interpreta-tion in examination of constitutional review cases is indefinite.

The similar situation happened in MK during the review of the constitutionality of Laws. In constitutional review cases, the Court does not necessarily requisite to provide an interpretation of constitutional article. The constitutional provision in the review cases are used mostly as a ground to review the constitutionality of Law. It is a tool of reference to check whether the Laws is in conformity with the constitution or not. The constitutional provision is not the object of review, thus the Court need not to give interpretation. On the other hand, the Law in question is a subject of review, accordingly the Court have to discuss at length on the issue. In other words, the Court provides a statutory interpretation to the Law in question. This paper argues that MK does not have any legal-formal obligation to interpret any articles in the Constitution especially when the Court consider it has a clear meaning. Nonetheless, the Court is bound to give reasoned deliberation in its decision making. In doing so, the Court does not make any boundary on the way of serving interpretation, whether it is a constitutional or statutory interpretation. There is few studies that provide information on how MK interpret the constitution, ${ }^{2}$ however none of which focuses on the distinction between constitutional and statutory interpretation. Therefore, it is important to set the background prior to discussing how the court applies constitutional or statutory interpretation in judicial review cases. In that notion, the first part of the discussion in this essay is to draw the debate among scholars on distinction between constitutional interpretation and statutory interpretation. Afterward, this essay

Muchamad Ali Safaat, Aan Eko Widiarto and Fajar Laksono, "Pola Penafsiran Konstitusi dalam Putusan Mahkamah Konstitusi Periode 2003-2008 dan 2009-2013", Jurnal Konstitusi, Vol. 14 No. 2, Juni 2017, p. 243; Tanto Lailam, "Penafsiran Konstitusi dalam Pengujian Konstitusionalitas Undang-Undang terhadap Undang-Undang Dasar 1945, Jurnal Media Hukum, Vol. 21 No. 1, 2014, p. 93. will turn to survey the Court's decisions to seek common approach employed as a method to solve the constitutional cases. The research aims to seek any pattern commonly used by the Court to interpret the Constitution, as well as to interpret the statute that was in question.

\section{Discussion}

\section{Distinguishing Constitutional and Statutory In- terpretation}

Some constitutional scholars argue that the constitutional interpretation differs from the statutory interpretation. ${ }^{3}$ It is not only due to the constitution's hierarchical position in a legal order but also the abstract nature of most constitutional provisions made the constitution differ from statute. Hence, the difference between statutes and constitution is the political nature of constitutional provisions. The constitutional norms are much more abstract than the statutory norms. The constitution considers as more political because the issues are highly at stake. It concerns the structure of society and the institutional arrangement of bodies that hold political power.

However, there are some scholars that rejected the distinction. They argue that a distinction between constitutional and statutory interpretation in terms of nature is somehow myth and harmful. ${ }^{4}$ Andras Jakab stated that "...the methods of constitutional interpretation are thus not different from the methods of statutory interpretation, only the emphasis placed on the specific methods and the frequency of their use are different." ${ }^{5}$

In a study which comparing the constitutional interpretation by referring to the US Supreme Court as the representation of common law system with the German Constitutional Court as one of the homes of civil law found that

3 Kevin M. Stack, "The Divergence of Constitutional and Statutory Interpretation", University of Colorado Law Review, Vol. 75 No. 1, March 2004, p. 2; Hon. Antonin Scalia and John F. Manning, "A Dialogue on Statutory and Constitutional Interpretation", The George Washington Law Review, Vol. 80, 2012, p. 1610-1612.

4 Andras Jakab, "Judicial Reasoning in the Constitutional Courts: A European Perspective", German Law Journal, Vol.14 No. 8, August 2013, p.1225.

5 Ibid. 
there was no significant difference between the two. The study concluded that

"... the difference between the common law and civil law traditions regarding legal reasoning is not crucial to constitutional interpretation because both German and US constitutional adjudicators supply a meaning to the abstract constitutional provisions based on their value choices. In this context, German constitutional interpretation has more similarities than differences with its US counterpart."

As an influential representative of civil law tradition, legal positivism is deeply rooted in the German legal system. The principle of positivism is that the law should be separated from morals, politics, and other fields. Instead, the law should be based on reason and logic. ${ }^{7}$ The judiciary function as mechanical application of legal rules. However, a further development shows that the positivist legal tradition is not merely legitimate basis in the constitutional adjudication. The authority to conduct constitutional review adopted in civil law countries has blurred the line between constitutional interpretation and statutory interpretation.

The practice of judicial review in the civil law countries serves space to the judiciary to make interpretation of the constitution for measuring the constitutionality of the norm in Laws and not just to interpret the Laws. ${ }^{8}$ An example of this is ruled issued by the German Federal Constitutional Court in Princess Soraya case. ${ }^{9}$ Princess Soraya is the former wife of the Shah of Iran who filed a constitutional case for defamation by Die Welt magazine for publishing a fic-

6 Mher Arshakyan, "The Impact of Legal System on Constitutional Interpretation: A Comparative Analysis: The US Supreme Court and the German Federal Constitutional Court",German Law Journal, Vol.14 No. 08, August 2013, p. 1324.

7 Donald P. Kommers, 1997, The Constitutional Jurisprudence of The Federal Republic of Germany, Durham and London: Duke University Press, p.40

8 D. Neil Mac Cormick and Robert P. Sommers (eds.), 1991, Interpreting Statutes: A Comparative Study, Aldershot: Dartmouth Publishing Co. Ltd., p.37; Joseph Dainow, "The Civil Law dan the Common Law: Some Points of Comparison", The American Journal of Comparative Law, Vol. 15, No. 3 (1966 - 1967), p. 419-435

9 Princess Soraya Case (1973), 34 Federal Constitutional Court of Germany 269, Decision of the Second Senate. titious interview which disclosed her personal life. She claims civil damages for this act yet the laws in Germany remains silent. Defamation is a criminal issue and not regulated under German civil law. In consequence, the injured party for defamation does not obtain any compensation. The Federal Constitutional Court ruled to grant Princess Soraya's petition and added civil law rule which previously did not regulate the remuneration of indemnification for defamation. The law is controversial since the German Basic Law stipulates that judiciary is bound by law and justice. Therefore, the Federal Constitutional Court cannot change legislation issued by Parliament. On this restriction, the Federal Constitutional Court coined the socalled holistic method of legal interpretation.

"The interpretation is the method and way by which the judge inquires into the content of a statute, considering its placement within the whole legal order, with out being restricted by the formal wording. ... the law is not identical with the whole of the written statutes. Over and above the positive enactments of the state power there can be 'ein Mehr an Recht' (a surplus of law) which has its source in the constitutional legal order as a holistic unity of meaning, and which can operate as a corrective to the written law; to find it and to deliver it in decisions is the task of adjudication." 10

The German Constitutional Court, in a way, adopted the American vision of law. The common law tradition embedded the vision illustrated by Oliver Wendell Holmes's aphorism as "the life of the law has not been the logic, it has been experience." The Court is guided not only by logic and reason but the decisions are also provided by the judges' experience, necessities of the time, the prevalent moral and political theories. ${ }^{11}$

10 Daniel A. Farber. "Hermeneutic Tourist: Statutory Interpretation in Comparative Perspective", Cornell Law Review, Vol. 81, No. 2, January 1996, p. 520 (the author provide translation to English on Princess Soraya Case).

11 Oliver Wendell Holmes, Jr., 2000, The Common Law, Project Gutenberg, Available on website: http://www. gutenberg.org/files/2449/2449-h/2449-h.htm, accessed on January $20^{\text {th }}, 2018$. 
The question on constitutional review is not only about legitimacy but also about the proper methods of constitutional interpretation. The constitution served to safeguard fundamental values and unifying the nation. On the other hand, the constitution should also be flexible enough to address social changes. To evolve, it can only be achieved through interpretation. Some scholars argue that Constitution is subject to special interpretive methods as comparing to other sources of law. They coined it as "constitutional exceptionalism". ${ }^{12}$ Chemerinsky also once said that " ... if the Constitution is to serve its functions of protecting fundamental values and unifying society, the judiciary should have substantial discretion in determining the meaning of specific constitutional provisions." 13 The interpretation of the Constitution will be supplied by judges based on contemporary values. He, then, added that "... any attempt to define limits on interpretation process or find an interpretation model will eventually fail because constitutional interpretation is indeterminate. ${ }^{14}$ It is because that there is no single correct answer to the vast majority of constitutional cases presented before the court.

\section{The Court Discretion to Interpret the Consti- tution}

As Chemerinsky note that judiciary should have "substantial discretion" in interpretation process, the question is to what degree is the discretion should be applied? In the US Supreme Court practices, judges have a high degree of discretion. A few factor made to the conclusion are: first, the difficulties for the identification of the ratio decidendi; second, the indeterminacy of precedents; third, the possibility of a new case arising that is not covered; and fourth, the under-determination of analogical reasoning. ${ }^{15}$

12 Christopher Serkin and Nelson Tebbe, "Is the Constitution Special?”, Cornell Law Review, Vol. 101, 2016, p. 702.

13 Erwin Chemerinsky, 1987, Interpreting The Constitution, New York: Preager, p. 126.

14 lbid.

15 Federico Jose Arena, "Which Kind of Discretion in Constitutional Adjudication? A Discussion of Mher Arshak yan's The Impact of Legal Systems on Constitutional Interpretation: A Comparative Analysis: The U.S. Supreme
In Indonesia, the use of principles embodied in the Constitution as the basis to review the Laws is part of the discretion despite its low occurrence. In some cases, the legal argument in the decision of the Court does not refer to an article in the Constitution. Rather, the Court explicitly named a set of constitutional value as the ground to review the constitutionality of the Law. The study found few rulings to be highlighted where the court uses legal principles namely the principle of justice and presumption of innocence.

The use of the principle of justice is seen in the Court decision on the requirement to run for head of local government. The Law on Local Government on article 59 paragraph (5) letter $\mathrm{g}$ Law Number 12 Year 2008 requires public servant to resign from their post if he is running as a candidate for head of local government. This condition was challenged by a citizen who was a public official intended to run for mayor of Bandarlampung. ${ }^{16}$ The petitioner argues that the requirement is unconstitutional because it is against "equal treatment" principle as implicitly stipulated in article 28D (1) of the Constitution, "every person shall be entitled to recognition, guarantee, protection and equitable legal certainty as well as equal treatment before the law". In comparison, he puts forward the example of public official who runs for the second term in office did not have to resign. In the decision, the Court concluded that "... it is not considered as unjust if there are offices which have different election process." The court is soundless on consideration of Article 28D (1) on the Constitution. However, the Court expressed that "justice" is not always an equal treatment. Justice, as the Court stated, can be defined as "... treat differently on two different things is justice. On the contrary, it is unjust to have equal treatment on two different things." 17

In terms of the notion of presumption of innocence, it was reviewed by the Court in a case brought by a former regent of Sarolangun.

Court and the German Federal Constitutional Court", German Law Journal, Vol 14 No 8, August 2013, p. 1339.

16 The Verdict of Constitutional Courts of Republic of Indonesia Number 4/PUU-VIII/2010.

17 Ibid., para. [3.21]. 
He was dismissed from the office by the Ministry of Interior because of corruption allegation, as it was regulated by Law. ${ }^{18}$ The petitioner argues that the Law is unconstitutional since there was no final decision delivered by the Special Court for Corruption cases yet. The Ministry and the Law, according to the petitioner, have breached his constitutional right of presumption of innocence. The Constitution does not clearly mention "presumption of innocence" as one of the citizen's rights. However, the Court raised and consider it as implied rights. The Court argues that "...it is important to assert that presumption of innocence is a principle in criminal law that protects the right of defendant to be presumed innocent until a legally binding decision imposed. Such right is guaranteed by the Constitution, as part of the rule of law, in addition, it is a part of civil and political right which must, therefore, be respected, protected, and be guaranteed." 19 Government action to discharge the petitioner from the office is considering inappropriate act and against the basic notion of presumption of innocence.

As a comparison, in the US, presumption of innocence finds its constitutional basis in Due Process Clause within the US Constitution. It is a fundamental principle in American Criminal Law which rooted back from the Magna Carta then reinforced the principle within common law tradition. ${ }^{20}$ In contrast, in civil law tradition especially in France, the principle has rooted back since medieval with the formulation of the principle "innocent until proven guilty" introduced by Johannes Monachus. ${ }^{21}$

\section{The Court's Interpretation to the Constitutio- nal Provision}

In its reasoning within the decisions, the Constitutional Court provides an interpretation

18 Article 31 (1) Law Number 12 Year 2008.

19 The Verdict of Constitutional Courts of Republik of Indonesia Number 024/PUU-III/2005, p. 36-37.

20 Shima Baradaran, "Restoring the Presumption of Innocence”, Ohio State Law Journal, Vol 72 No 4, 2011, p. 727

21 Francois Quintard-Morenas, "The Presumption of Innocence in the French and Anglo-American Legal Traditions, The American Journal of Comparative Law, Vol. 58 Issue 1, January 2010, p. 114-116. to the constitutional provision before examining the constitutionality of the Law under review. Few examples of which are when the Court interpreted the phrase "state-controlled right" as stipulated in Article 33 of the 1945 Constitution and the arrangement to hold simultaneous elections.

Article 33 paragraph (2) and (3) of the Constitution stipulated that "Sectors of production which are important for the country and affect the life of the people shall be under the powers of the State" and "The land, the waters and the natural resources within shall be under the powers of the State and shall be used to the greatest benefit of the people". ${ }^{22}$ The notion of "under the power of the state" or "under statecontrolled" have been long-debated. ${ }^{23}$ In the review of electricity law (Law No. 20 of 2002) case, the court put a strong emphasis on the need to give explanation to the notion of "state-controlled" before examining the constitutionality of electricity law.

The Court provides that "state-controlled" consisted of five cumulative elements: policy making (beleid), administrative (bestuursdaad) managerial (beheersdaad), supervisory (toezichthoudensdaad) and regulation (regelendaad). ${ }^{24}$ Many argue that these elements are influenced by the writings of Wolfgang Friedmann. ${ }^{25}$ In his idea of welfare state, Friedmann closely related his argument to the state primary function as: first, provider of social services; second, regulator of private economy; third, entrepreneur of a nationalized public sector; and fourth, umpire. ${ }^{26}$

Within this newly developed understanding on the notion of "state-controlled", the Court uses the same framework to examine on

22 Translation to english as provided on www.constitute project.com

23 Kuntana Magnar, Inna Junaenah and Giri Ahmad Taufik, "Tafsir MK atas Pasal 33 UUD 1945: Studi Atas Putusan MK Mengenai Judicial Review UU No. 7/2004, UU No. 22/2001, dan UU No. 20/2002, Jurnal Konstitusi, Vol. 7 No. 1, February 2010, p. 120-121.

24 The Verdict of Constitutional Courts of Republik of Indonesia Number 001-021-022/PUU-1/2003, p. 334.

25 Mohamad Mova Al'afghani, "The Elements of State Control", the Jakarta Post, January 14th, 2013.

26 Wolfgang Friedmann, 1971, The State and The Rule of Law in A Mixed Economy, London: Stevens, p.5 
other constitutional cases. For example, in the review of the Law on Oil and Gas (Law Number 22 Year 2001$)^{27}$ and in the review of water resources law (Law Number 7 Year 2004). ${ }^{28}$

Another interpretation provided by the Court on constitutional provision is on the arrangement of election. After the downfall of Suharto, Indonesia has successfully held national and local elections. In terms of national election, the electoral process for members of parliament was held separately with the presidential election. The constitution is quiet on this issue. However, a petition was filed before the Court challenging this type of arrangement as stipulated in the Law on Presidential Election (Law Number 42 Year 2008). ${ }^{29}$ They argue that election for member of parliament and the President should be held simultaneously.

The Court found that the issue has been discussed in the drafting of the constitutional amendment. The intent of the drafters was clear. The constitutional drafters have reached an agreement on the definition of "election". A consensus has been attained that "... the words election means for election for member of House of Representatives, election for House of Regional Representatives, election for President and Vice President and election for member of Regional House of Representatives. Thus, they placed in one arrangement." 30 In a more technical arrangement, as an illustration, the voting booth will consist of five boxes: for DPR, for $D P D$, for the president and vice president, for Provincial Parliament and for Regency/City Parliament. ${ }^{31}$ Therefore, Article 22E (2) of the Constitution must be read in close relation to Article $6 \mathrm{~A}(2)$ of the Constitution. After the decision, there are consequences for the prepara-

27 The Verdict of Constitutional Courts of Republik of Indonesia Number 002/PUU-1/2003

28 The Verdict of Constitutional Courts of Republik of Indonesia Number 058-059-060-063/PUU-II/2004 and 008/ PUU- III/2005

29 The Verdict of Constitutional Courts of Republik of Indonesia Number 14/PUU-X/2013

30 Ibid., p. 82

31 Tim Penyusun, 2010, Naskah Komprehensif Perubahan Undang-Undang Dasar Negara Republik Indonesia Tahun 1945, Latar Belakang, Proses, dan Hasil Pembahasan 1999-2002, Buku V Pemilihan Umum, Jakarta: Sekretariat Jenderal dan Kepaniteraan Mahkamah Konstitusi, p. 602. tion to hold simultaneous election, especially on the electoral management. ${ }^{32}$

\section{The Court's Approach to Interpret Competing Constitutional Rights}

The Amendment of the 1945 Constitution made major changes, especially in adoption of provisions concerning constitutional rights. The protection of these rights is the Court task. Every government policies should not violate citizens rights. In many cases, provisions on the protection of constitutional rights do not require any exceptional exegesis. Yet, few example also exists where the Court needs to find the meaning of "discrimination" and referring it to the international legal instruments. ${ }^{33}$

In practice, the court applies more than one constitutional provision on the protection of citizen's rights. Hence, it opposes the intersection of rights or competing rights. ${ }^{34}$ For instance, in a decision to review the constitutionality of the Law that set forth administration requirement necessarily fulfilled by political parties in order to be participant in election the Court found that

"... freedom within the state based on rule of law must be regulated in a Law in order to ensure, few among other things, equality before the law [as require in Article 27 (1) UUD 1945] as well as freedom of association and assembly [as require in Article 28 UUD 1945]. Nonetheless, the Court found, as stated in the Constitution that freedom, both as a concept and action, is not limitless. Freedom is paradoxical when if detached it may bring damage/destruction to itself. Freedom for the majority or certain groups may always have the possibility to be limited merely to respect and maintain freedom of other [as stated in Article 28J (2) UUD 1945]." 35

32 Sri Nuryanti, "Menyiapkan Tata Kelola Pemilu Serentak 2019", Jurnal Penelitian Politik, Vol. 12 No. 1, 2015., p. 3.

33 Decision Number 011-017/PUU-I/2003, p. 34-35.

34 Ontario Human Rights Commissions, n.d., "Policy on Competing Human Rights", Available on website http:// www.ohrc.on.ca/en/policy-competing-human-rights, accessed on January $20^{\text {th }}, 2018$.

35 The Verdict of Constitutional Courts of Republic of Indonesia Number 52/PUU-X/2012, para. [3.15]. 
The Court also takes account of balancing when examining the application of an ex-post facto law in the review of human rights court Law (Law Number 26 Year 2000). ${ }^{36}$ The Court found that Article 28I (1) of the Constitution must be read with the Article 28J (2). Both articles show that the right not to be prosecuted under a retroactive law is not absolute. The right can be set aside in order to fulfill fairness in accordance with moral, religion, security and order. ${ }^{37}$ The court further provides that the parameters to determine a balance in legal certainty and fairness must be conducted by considering three objectives of law: legal certainty (rechtssicherkeit), fairness (gerechtigkeit), and legal practical (zweckmassigkeit). Taking these into account in a balanced manner, the retroactive law may be justified in a limited fashion, for instance, to enforce the law on extraordinary crimes. ${ }^{38}$ If the case concern on the protection of rights, there are scholars who argue that judges should put more weight to rights and less weight to the public interest. ${ }^{39}$

In these cases, MK implied the need to adopt proportionality principle to seek the balance between competing rights. The court once mentions that "...proportionality constitutes principle and morality of the Constitution, which can be applied as justification to set aside constitutional rights". ${ }^{40}$ This notion is derived from the application of Article 28J (2) UUD 1945 which allows the exclusion of human rights in a careful, meticulous and thorough measures.

However, the Court has yet to develop measures to test the principle of proportionality. It is different apart from other constitutional adjudication in other countries where proportionality have transcended beyond borderlines. ${ }^{41}$ It also evolves from a principle of more

36 The Verdict of Constitutional Courts of Republic of Indonesia Number 065/PUU-II/2004.

37 Ibid, p. 51.

38 Ibid, p. 52.

39 Denise Meyerson, "Why Courts Should Not Balance Rights Against the Public Interest, Melbourne University Law Review, Vol 31, 2007, p. 902.

40 The Verdict of Constitutional Courts of Republic of Indonesia Number 9/PUU-VIII/2009, para. [3.23].

41 Imer B. Flores, "Proportionality in Constitutional and Human Rights Interpretation”, Problema: Anuario de Filosofia y Teoria del Derecho, No. 7, 2013, p. 86. philosophy to a legal principle and from a principle of administrative law to a principle of constitutional law. ${ }^{42}$ As a comparison, the doctrine of proportionality is associated with the decision of the Supreme Court of Canada in the case of $R$ $v$. Oakes. The Supreme Court formulated a test to allow limitation of rights by Law if they fulfill specific requirements. The test formulated as

"First, the measures adopted must be carefully designed to achieve the objective in question. They must not be arbitrary, unfair or based on irrational considerations. In short, they must be rationally connected to the objective. Second, the means, even if rationally connected to the objective in this first sense, should impair "as little as possible" the right or freedom in question. Third, there must be a proportionality between the effects of the measures which are responsible for limiting the Charter right or freedom, and the objective which has been identified as of "sufficient importance." 43

A simple way of analysis by using proportionality test is by making few assumption. Assuming that the purpose of the lawmakers to enact Law is "A". To achieve "A", two roads may be taken: "X-1" and "X-2". Each road may cause violation to the constitutional rights. Losses were presented with " $Y$ ". If calculated, " $X$ 1 " has potential losses far greater than " $X-2$ ". However, the Lawmakers choose to take " $X-2$ " to achieve "A". The political consideration of the lawmakers is that it is faster than " $X-1$ ". The law then is verified before the Court. The Court applies the proportionality test to measure the political choices of the Lawmaker. Based on examination of evidence and applying proportionality test, the Court may decides that although "X-1" is faster to reach " $A$ " (the goal) yet it potentially cause far greater damage to the citizen. Therefore, "X-1" should be annulled in order to protect the citizen's constitutional rights and it is contrary to the constitutional value.

\footnotetext{
42 Bernhard Schlink, "Proportionality in Constitutional Law: Why Everywhere but Here?", Duke Journal of Comparative Law and International Law, Vol 22, 2012, p. 302.

$43 \quad R$ v Oakes [1986] 1 S.C.R. 103.
} 
The test is known as the "Pareto way" due to its resemblance to the theory of "pareto-optimality" in economics. The idea is how to achieve the goal by measuring the risks of loss of each policy considered. The policy that has to be taken is the one that earns more but has the least potential loss. ${ }^{44}$ In legal terms, Robert Alexy introduced the rule on "Law of Balancing" which stated " $(\mathrm{t})$ he greater the degree of nonsatisfaction of, or detriment to, one principle, the greater must be the importance of satisfying the other". ${ }^{45}$

The Constitutional Court has not developed any certain measurement as to establish proportionality test. The court has considered in balancing the competing rights. Yet, a standard parameter has not been developed. A constitutional justice, Maruarar Siahaan, has offered his insight in his dissenting opinion. He argued that:

"... the test can be done either by "Direct Synchronization Test" or "Indirect Synchronization Test", which is by comparing the Laws. ...interpretation is allowed to the extent that it does not violate the order of Laws, so the Laws should not cast any ambiguity or inconsistency." 46

\section{The Absence of Constitutional Ground in Chal- lenging the Law}

The border between constitutional and statutory interpretation is hard to distinguish in a case where the Court does not refer to any constitutional provision, nor a provision on constitutional right. An example of this type of ruling is in the Court decision on the review of Law on Farming and Animal Health (Law Number 18 Year 2009). ${ }^{47}$ The petition challenges four articles in the Law for its conformity with the Constitution. The court decides to take a careful step by elucidating legal consideration on each article separately. The problem emerges in the

44 Alec Stone Sweet and Jud Mathews, "Proportionality Balancing and Global Constitutionalism", Columbia Journal of Transnational Law, Vol. 47, 2008, p. 96.

45 Robert Alexy, "Constitutional Rights, Democracy, and Representation, Richerche Giuridiche, Vol. 3, No. 2., December 2014, p.200

46 The Verdict of Constitutional Courts of Republic of Indonesia Number 006/PUU-I/2003, p.112

47 The Verdict of Constitutional Courts of Republic of Indonesia Number 137/PUU-VII/2009.
Court argument on the constitutionality of article 59(2) of the Law. The Law requires that imported fresh animal products from a business unit from a country of within certain area in the country must meet the requirement and procedure of animal product. ${ }^{48}$ The petition question the terms "animal product business unit from the country within certain area".

A thorough reading of the Court argument found that there is an absence of constitutional article as the ground to review the challenge Law. In a nutshell, the Court came to a decision that the article is in conformity with the constitution without mentioning any provision in the Constitution as its constitutional ground of consideration. The Court took an unprecedented approach in which it uses legal principle as its ground of consideration. In the decision, the Court elaborated the condition of "welfare state" and the principle of "prudence" as part of good governance principle. The Court raises the notion of welfare state, where the Court discusses that

"... in the welfare state, the government must actively participate in the economy, including the issuance of regulations that protect and push towards welfare. In order to protect the public against the possibility of losses in the economy, the Government should issue regulations guaranteeing to that direction." 49

In addition, the Court also emphasized the need for the government to act cautiously when it comes to the policy of importation of fresh animal products. The country origin must meet the requirements and procedure of importation animal products.

The Court concluded the law is in contrary to the 1945 Constitution. However, the Court did not provide any further reason the use of welfare state and prudential principle as the

48 Article 59 (2) of Law Number 18 Year 2009 states, "fresh animal products are imported into the territory of the Republic of Indonesia as referred to in paragraph (1) letter a shall come from animal products business unit in a country or zone of a country has met the requirements and procedures for the importation of animal products".

49 The Verdict of Constitutional Courts of Republik of Indonesia Number 137/PUU-VII/2009, p. 133. 
ground to annulled the Law. Furthermore, the Court does not associate these principles either in relation to the constitution, whether the principle is implied in the constitutional provision and whether there is a crucial reason for using theses principle as a constitutional value. One may assume that this is a part of the Court discretion in the constitutional review. The ability to make discretionary decision in constitutional case is central to the mechanics of democratic constitutionalism. The fact that there is a space in the Constitution for the judges to interpret helps ensure that the nation remains bound together by the project of interpreting constitutional texts. ${ }^{50}$

\section{Conclusion}

The role of MK to examine the constitutionality of Law requires the Court to conduct constitutional interpretation. A few decision shows the Court provides an interpretation of the constitutional provisions. The phrase "the right to control the state" as stipulated in Article 33 of the Constitution and the provisions on the holding simultaneous election as discussed in the drafting of constitutional amendment to the Article $6 \mathrm{~A}$ and $22 \mathrm{E}$ of the Constitution are examples of constitutional interpretation given by the Court.

In constitutional review cases, the Court does not only interpret the constitution but also adopted statutory interpretation. This practice is part of the Court's attempts to protect constitutional rights. The constitutional provision that rules on the protection of constitutional rights are not commonly a single challenge. The issue mostly related and cover different constitutional provision that leads to the issue of competing rights. In this context, the Court considers using a balanced approach in the exercise of those rights. Nonetheless, the Court lacks a body jurisprudence in regards to measure the proportionality between these competing rights.

A glaze over boundary line between constitutional interpretation and statutory interpretation is also identified in the decisions in

50 Todd E. Pettys, Judicial Discretion in Constitutional Cases, Journal of Law and Politics, Vol. 26, 2011, p. 140. which the Court uses fundamental principles without any reference to a certain constitutional provision. The practice is regarded as a judicial discretion in deciding constitutional review cases. At a certain point, the extent of judicial discretion will need to have its limitations. A lack of precedent on the issue is a room for development for the Court to consider on any limitation to judicial discretion for the sake of the Court's own future.

Understanding court decisions is never an easy task. Ralph Christensen, a German legal linguist, once revealed that "Courts don't do what they say, and they don't say what they do". The aphorism implies difficulties in trying to understand how courts, including the Constitutional Court, come to their judgments. However, herein lies the challenges and the appeal in the study of constitutional law and constitutional courts.

\section{References}

Al'afghani, Mohamad Mova. "The Elements of State Control". The Jakarta Post. January 14th, 2013.

Alexy, Robert. "Constitutional Rights, Democracy, and Representation". Richerche Giuridich. Vol. 3 No. 2. December 2014. Pp. 197-209. DOI: 10.14277/2281-6100/Ri-3-214-1;

Allan, James. "Constitutional Interpretation v. Statutory Interpretation: Understanding the Attractions of "Original Intent". Legal Theory. Vol. 6 No. 1. March 2000. Pp. 109-126. DOI: $10.1017 / \mathrm{S} 13523252000610$ 48;

Arena, Federico Jose. "Which Kind of Discretion in Constitutional Adjudication? A Discussion of Mher Arshakyan's The Impact of Legal Systems on Constitutional Interpretation: A Comparative Analysis: The U.S. Supreme Court and the German Federal Constitutional Court". German Law Journal. Vol. 14 No. 8. August 2013. Pp. 13371344;

Arshakyan, Mher. "The Impact of Legal System on Constitutional Interpretation: A Comparative Analysis: The US Supreme Court and the German Federal Constitutional Court". German Law Journal. Vol.14 No. 08. August 2013. Pp.1297-1336; 
Baradaran, Shima. "Restoring the Presumption of Innocence". Ohio State Law Journal. Vol. 72 No. 4, 2011. Pp. 723-776;

Chemerinsky, Erwin.1987. Interpreting The Constitution. New York: Preager;

Dainow, Joseph. "The Civil Law dan the Common Law: Some Points of Comparison". The American Journal of Comparative Law. Vol. 15, No. 3. 1966-1967. Pp. 419435;

Farber, Daniel A. “Hermeneutic Tourist: Statutory Interpretation in Comparative Perspective"Cornell Law Review. Vol. 81 No. 2. January 1996. Pp. 513-529;

Feldman, David. "Statutory Interpretation and Constitutional Legislation". Law Quarterly Review, Vol. 130. 2014. Pp. 473-497;

Flores, Imer B. "Proportionality in Constitutional and Human Rights Interpretation". Problema: Anuario de Filosofia y Teoria del Derecho , No. 7. 2013. Pp.83-113;

Friedmann, Wolfgang. 1971.The State and The Rule of Law in A Mixed Economy, London: Stevens.

Greenwalt, Kent. “Are Mental States Relevant for Statutory and Constitutional Interpretation”. Cornell Law Review. Vol. 85 Issue 6. 2000. Pp. 1609-1672;

Holmes, Oliver Wendell Jr. 2000. "The Common Law. Project Gutenberg". Available on website: http://www.gutenberg.org/files /2449/2449-h/2449-h.htm. accessed on January $20^{\text {th }} 2018$;

Jakab, Andras. "Judicial Reasoning in the Constitutional Courts: A European Perspective". German Law Journal. Vol.14 No. 8. August 2013. Pp.1215-1278;

Kommers, Donald P. 1997.The Constitutional Jurisprudence of the Federal Republic Of Germany. Durham and London: Duke University Press.

Lailam, Tanto. "Penafsiran Konstitusi dalam Pengujian Konstitusionalitas Undang-Undang terhadap Undang-Undang Dasar 1945". Jurnal Media Hukum. Vol. 21 No. 1. 2014. Pp. 88-106;

Mac Cormick, D. Neil and Robert P. Sommers (eds.). 1991. Interpreting Statutes: A Comparative Study, Aldershot: Dartmouth Publishing Co. Ltd;

Magna, Kuntana. Junaenah, Inna and Taufik, Giri Ahmad. "Tafsir MK atas Pasal 33 UUD
1945: Studi Atas Putusan MK Mengenai Judicial Review UU No. 7/2004, UU No. 22/2001, dan UU No. 20/2002". Jurnal Konstitusi. Vol. 7. No. 1. February 2010. Pp. 111-180;

Meyerson, Denise. "Why Courts Should Not Balance Rights Against the Public Interest". Melbourne University Law Review. Vol. 31. 2007. Pp. 873-902;

Nuryanti, Sri. "Menyiapkan Tata Kelola Pemilu Serentak 2019”. Jurnal Penelitian Politik. Vol. 12 No. 1. 2015. Pp.1-14;

Ontario Human Rights Commissions. n.d.. "Policy on Competing Human Rights". Available on website http://www.ohrc. on.ca/ en/policy-competing-human-rights. Accessed on January $20^{\text {th }}$. 2018;

Pettys, Todd E. “Judicial Discretion in Constitutional Cases". Journal of Law and Politics. Vol. 26 No. 1. 2011. Pp. 123-179;

Quintard-Morenas, Francois. “The Presumption of Innocence in the French and Anglo-American Legal Traditions, The American Journal of Comparative Law”. Vol. 58 Is-sue 1. January 2010. Pp. 107-149. DOI: 10.5131/ ajcl.2009.0005;

Safaat, Muchamad Ali. Widiarto, Aan Eko and Laksono, Fajar. "Pola Penafsiran Konstitusi dalam Putusan Mahkamah Konstitusi Periode 2003-2008 dan 2009-2013". Jurnal Konstitusi. Vol. 14 No. 2. Juni 2017. Pp. 234-261;

Scalia, Antonin and Manning, John F. "A Dialogue on Statutory and Constitutional Interpretation". The George Washington Law Review. Vol. 80 No. 2. November 2012. Pp. 1610-1619;

Schlink, Bernhard. "Proportionality in Constitutional Law: Why Everywhere but Here?". Duke Journal of Comparative Law and International Law. Vol. 22. 2012. Pp. 291 302;

Serkin, Christopher and Tebbe, Nelson. "Is the Constitution Special?". Cornell Law Review. Vol. 101. 2016, pp. 701-776;

Stack, Kevin M. "The Divergence of Constitutional and Statutory Interpretation". University of Colorado Law Review. Vol. 75 No. 1. March 2004. Pp.2-53;

Sweet, Alec Stone and Mathews, Jud. "Proportionality Balancing and Global Constitutionalism". Columbia Journal of Transnational Law. Vol. 47. 2008. Pp. 73-165. 